\title{
INTEGRATED FLOOD STUDY OF BAGMATI RIVER BASIN WITH HYDRO PROCESSING, FLOOD INUNDATION MAPPING \& 1-D HYDRODYNAMIC MODELING USING REMOTE SENSING AND GIS
}

\author{
A.K. Rastogi ${ }^{1}$, P.K. Thakur ${ }^{2 *}$, G. Srinivasa Rao ${ }^{3}$, S.P Aggarwal ${ }^{2}$, V.K.Dadhwal ${ }^{4}$, P. Chauhan ${ }^{2}$ \\ 1* Excecutive Engineer, Water Resources Department, Govt. of Bihar- akrastogi30@ gmail.com \\ ${ }^{2}$ Water Resources Department, Indian Institute of Remote Sensing, Dehradun, (praveen, spa, prakash)@iirs.gov.in \\ ${ }^{3}$ Indian Space Research Organization (ISRO), Bangalore, India, gsrao@ @isro.gov.in \\ ${ }^{4}$ Indian Institute of Space Science and Technology (IIST), Trivandrum, Kerala, India - vkdadhwal@iist.ac.in
}

Commission V, SS: Natural Resources Management

KEY WORDS: Floods, Hydro-Processing, Bihar, Bagmati River, Radarsat, Hydrodynamic model, Flood Inundation

\begin{abstract}
:
Flood is one of the most the most re-occurring natural hazard in the state of Bihar, as well as in India. The major rivers responsible for flood in the state of Bihar are Kosi, Gandak, Ghagra and Bagmati, which are the tributary rivers of Ganges. The head water catchment area of these rivers lies in the Himalayan state of Nepal. The high rainfall in Nepal, siltation of hydraulic structures, rivers and low topography of North Bihar causes flood occurrence in these areas on regular basis. Remote sensing and GIS plays an important role in mapping, monitoring and providing spatial database for all flood related studies. The present work focuses on the use remote sensing based topography and images in GIS environment for integrated flood study of Bagmati River, which is one of the most flood prone rivers of North Bihar. The Digital Elevation Model (DEM) from shuttle radar topography mission (SRTM) was used to create detailed sub-basin and river network map of entire Bagmati basin. The floods of July-August 2002 were mapped using RADARSAT-1 data using threshold based method. The SRTM DEM and ground based river cross-section from Dheng to Benibad stretch of Bhagmati River were used to create 1-dimensional hydrodynamic (1-D HD) model for simulating flood water level, discharge and flood inundation. Validation of simulated flood flows was done using observed water level of central water commission (CWC) from Dheng to Runisaidpur stations, with coefficient of correlation of 0.85 . Finally, an integrated framework for flood modelling and management system is proposed.
\end{abstract}

\section{INTRODUCTION AND OBJECTIVES}

\subsection{Introduction}

The Indian region, due to its unique geo-climatic conditions, is highly vulnerable to natural disasters like flood, drought, cyclone, earthquake and landslides (Kumar 2004). Among the 36 states / union territories in the country 22 are disaster prone. The cause of flood is mainly the peculiarity of rainfall in the country, out of the total rainfall in the country, $75 \%$ is concentrated over a short monsoon season of 4 months from June to September which is of order of $117 \mathrm{~cm}$ on an average. About 40 million hectares or nearly $1 / 8$ th of country's geographical area is flood prone, and an average of 18.6 million hectares is flooded annually (MHA, 2011, NIDM-2011).

The states of Assam, West Bengal, Bihar, Uttar Pradesh (in Brahmaputra and Ganga Basins) and parts of Orissa experience extensive devastation due to floods more frequently (Seth, 1998). Average annual loss due to floods is 1,805 crore (GOI, 2006) in India. As per government of India report (2006), on an average about 7.55 million hectare of land area, 40.967 million of population, 1560 human lives, along with large number of livestock and houses are damaged annually due to flood (GOI, 2006). Flood losses in terms of life and property can be minimized, with combination of structural and non-structural measures, with short and long terms plans (UN, 2002). This can be a flood prediction, prevention, monitoring, warning, relief \& rehabilitation. These activities are generally part of nonstructural approach to flood management (UN, 2002, Kumar, 2004).

\footnotetext{
${ }^{*}$ Corresponding Author
}

Flood inundation mapping is an interdisciplinary exercise that involves geomorphic and remote sensing based methods. The flood mapping provides insight into the hydrologic and geomorphic linkage within a flood plain (Mertes et al., 1995; Poole et al., 2002). A geomorphic methods needs topographic data having a high vertical resolution to characterize floodplain areas. Whereas, remote sensing (space and airborne) systems, provides a cost-effective opportunity to collect spatial distributed data over large areas. There are number of remote sensing data available for mapping floodplains and flood inundation extent from optical and microwave sensors. For large alluvial valleys the infrared portion of the electromagnetic spectrum enables delineation of low lying inundated areas and boundary terraces (Birkett, 2000; Frazier and Page, 2000; Smith,1997; Toyra et al., 2002).

Traditional flood modelling methods does not take into account the spatial data, because the Digital elevation models (DEMs) are either not available or too coarse to adequately capture the subtle variations in floodplain topography important in characterizing the spatial variability of the hydro period regime (Townshed, 1998). Hydraulic models of overland flow allow river discharge to be related to flood inundation extent, and provide the capability to simulate flooding based on a scenario and actual discharge. Surface elevation remains one of the most important data for such models, as floodplain topography is the main variable that affects the movement of the flood wave, and the prediction of inundation extent (Bakimchandra, 2006). 
So an integrated approach of utilizing all data sources, flood models and inundation maps for response, recovery and mitigation activities during and after a flood event have to be developed. This method also uses calibration of flood models using historical data like River gauge and discharge for past peak floods, written records on past Flood events \& records from archives related to Flooding phenomenon, within a GIS platform could provide first-hand information for flood prevention decision making (Tholey et al., 1997).

\subsection{Objectives}

The main objectives of this work are,

- To derive full basin/sub-basin boundaries, stream network, configuration and physical characteristics of Bagmati River

- To develop a methodology to map the full extent of flood inundation during peak flood using active remote sensing

- To reconstruct the 2002 floods from Dheng to Benibad using hydrodynamic models.

- To create the integrated framework for Flood Management Information System for Bagmati River Basin.

\section{STUDY AREA, DATA AND METHODOLOGY USED}

\subsection{Study area}

The river Bagmati, one of the perennial rivers of North Bihar, originates in Shivpuri range of hills in Nepal at latitude $27^{\circ} 47^{\prime} \mathrm{N}$ and longitude $85^{\circ} 17^{\prime} \mathrm{E}, 16 \mathrm{~km}$ North-East of Kathmandu at an elevation of $1500 \mathrm{~m}$ above MSL. The river Bagmati traverses nearly $195 \mathrm{~km}$ in Nepal territory before it debauches into the plains. Thereafter it covers nearly $394 \mathrm{~km}$ in Bihar before out falling in the Kosi. It receives tributaries Lakhandai, Lalbakya and Adhwara system. The river ultimately out falls in Kosi at upstream of Baltara in Khagaria district. Its total catchments area is $13,424 \mathrm{~km}^{2}$ out of which $6,320 \mathrm{~km}^{2}$ lie in India. Its total length is $589 \mathrm{~km}$ (India-WRIS). The catchment of the Bagmati basin located on the south of the Himalayan range in Nepal and north of river Ganges in India and lies between the Burhi-Gandak basin on the west and the Kamla-Balan basin on the east. River passes through two distinctly different terrains. From the origin to a little upstream of the Indo-Nepal border the catchment is hilly and full of forest, whereas in the downstream up to its confluence with the Kosi, the catchment is almost plain.

The river Bagmati enters in Bihar in the village Shorwatia in Sitamarhi dist. nearly $2.5 \mathrm{~km}$ north of Dheng Railway Bridge. The main course of river in its first reach inside Indian territory crosses Samastipur - Narkatiaganj railway line near Dheng Railway station through railway bridge no. 89. The Bagmati river in this reach flows due for nearly $15 \mathrm{~km}$, up to village Khoripakar where the river Lalbakiya joins on its right bank. The passing through Kalanjarghat, it goes to Hayaghat. There DarbhangaBagmati joins on its left bank just $1.5 \mathrm{~km}$ above Hayaghat. After the confluence with Darbhanga- Bagmati it is commonly known as the Kareh. The last reach of the river Bagmati, from Hayaghat to Khormaghat, is the longest reach of $191 \mathrm{~km}$. In its $1^{\text {st }}$ reach, between village Shorwatia and the confluence pt. with Lalbakiya, the river has a tendency to shift towards west and spilling both its banks during high floods inundating areas in the Sheohar block. This reach is embanked on both the sides. In its $2^{\text {nd }}$ reach, between the confluence pt. with Lalbakiya and Kalanjarghat, the river is embanked in its right side, $51.46 \mathrm{~km}$ and in its left side, $53.24 \mathrm{~km}$.

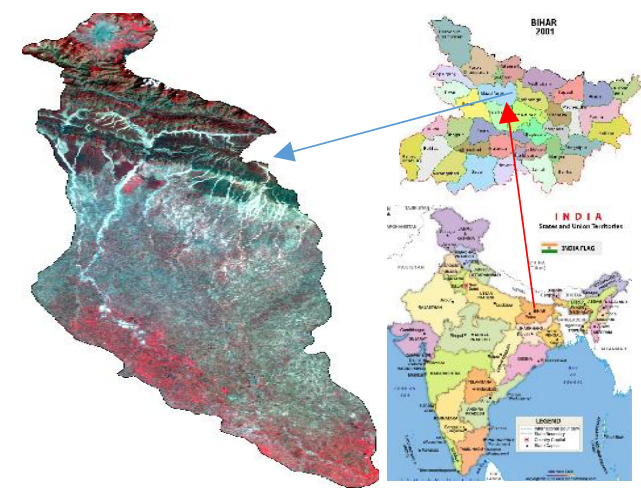

Figure 1.1. FCC map of Bagmati river basin with location map (Sources: NRSC and Maps of India)

In its $3^{\text {rd }}$ reach from Kalanjarghat to Hayaghat its not embanked. In its last reach from Hayaghat to Khormaghat the left bank is embanked from Hayaghat to Phuhia and the right bank is embanked from Hayaghat to Badlaghat. In this study, extent of the study area is from $26^{\circ} 02^{\prime} \mathrm{N}$ and $85^{\circ} 15^{\prime} \mathrm{E}$ to $26^{\circ} 46^{\prime \prime} \mathrm{N}$ and $85^{\circ} 45^{\prime} \mathrm{E}$, i.e., from Dheng railway bridge to Benibad is used for 1-D HD modelling and flood inundation mapping.

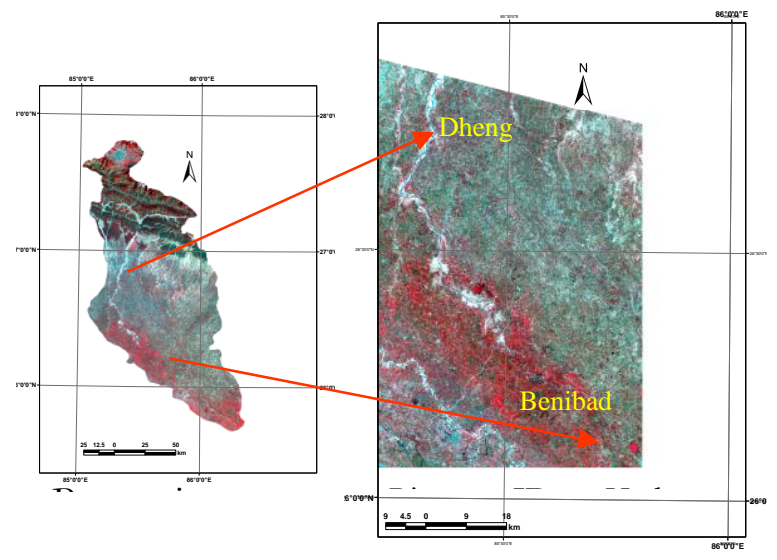

Figure 1.2. FCC map of Bagmati basin with HD model extent

\subsection{Flood problem in the study area}

The Bagmati River is an unstable one and has been shifting its course constantly within its meandering belt. River is braided only for a short distance from Noonthore in Nepal, where it emerges into plain up to Dheng. Below Dheng its of meandering type. Normal flooding is normal feature in some part of the river basin and abnormal floods are reported to have occurred once or twice every five years resulting in heavy damages to property and loss of life. During floods the river used to spill over its banks and inundate large part of lands in the Dist. of Sitamarhi, East Champaran, Muzaffarpur, Darbhanga, Samastipur and Khagaria. The flood is mainly due to heavy rains in the hilly catchment in Nepal which often synchronises with heavy rains in the plains lower down in India. (BSIC, 1994)

The Bagmati starts spilling over banks from $15 \mathrm{~km}$ upstream of Indo-Nepal border. The middle reach of the river section from Dheng Railway Bridge to Muzaffarpur-Darbhanga road crossing is wide and very shallow because most of the silt charge is largely deposited in this reach. The bankful capacity is not more than 560 cumecs, whereas the maximum observed discharge of the Bagmati at Dheng and Hayaghat sites are 3033 cumecs (1975) and 2618 cumecs (1975). This shows that flood in north-west 
areas above Sitamarhi-Muzaffarpur road is confined within embankments constructed on both sides of banks, whereas the south-east area in the lower part of the system is worse affected due to unembanked reach.(BSIC, 1994)

\section{Main flood problems of the river Bagmati are as follows:}

1. The river Bagmati inundates nearly $2370 \mathrm{~km}^{2}$ in Bihar causing extensive damage to lives and property almost every year.

2 . The carrying capacity of the river is very inadequate and does not cater even to $1 / 5$ th of its peak discharge. As a result of inadequacy of its channel capacity, the river carves out new spill channels.

3. The bed slope of main river course is almost flatter, $0.14 \mathrm{~m} / \mathrm{km}$ between Dheng railway bridge and Hayaghat, $0.4 \mathrm{~m} / \mathrm{km}$ between Hayaghat and Phuhia and $0.11 \mathrm{~m} / \mathrm{km}$ between Phuhia and Badlaghat. It also add to the spilling of river on its both banks.

4. Due to large scale spilling on it's both banks, at many places agricultural land gets submerged in flood water.

5. River basin suffers from acute drainage congestion due to numerous depression called "taals" and "chaurs" and old abandoned courses of the river.

\subsection{Data used}

Table 1 is given below, which gives summary of all remote sensing data from Indian and foreign satellites used in this work.

Table 1: data used in the present study

\begin{tabular}{|c|c|c|c|c|c|c|}
\hline $\begin{array}{l}\text { S.N } \\
\text { o. }\end{array}$ & Satellite & Sensor & $\begin{array}{l}\text { Spatial } \\
\text { Resolutio } \\
\text { n }\end{array}$ & $\begin{array}{l}\text { Path } \\
\& \\
\text { Row }\end{array}$ & Date & $\begin{array}{l}\text { Data } \\
\text { Source }\end{array}$ \\
\hline 1 & $\begin{array}{l}\text { IRS - P6 } \\
\text { (Resourcesat- } \\
\text { 1) }\end{array}$ & $\begin{array}{l}\text { LISS - } \\
\text { III }\end{array}$ & $23.5 \mathrm{~m}$ & $\begin{array}{l}104 \& \\
053\end{array}$ & $\begin{array}{l}24.3 .2006 \\
\text { (Pre } \\
\text { Flood) }\end{array}$ & NRSC \\
\hline 2 & $\begin{array}{l}\text { IRS - P6 } \\
\text { (Resourcesat- } \\
\text { 1) }\end{array}$ & $\begin{array}{l}\text { LISS - } \\
\text { III }\end{array}$ & $23.5 \mathrm{~m}$ & $\begin{array}{l}105 \& \& \\
053\end{array}$ & $\begin{array}{l}17.10 .200 \\
4 \\
\text { (Post } \\
\text { Flood) }\end{array}$ & NRSC \\
\hline 3 & $\begin{array}{l}\text { IRS - P6 } \\
\text { (Resourcesat- } \\
\text { 1) }\end{array}$ & AWIFS & $56 \mathrm{~m}$ & $\begin{array}{l}103 \& \\
053\end{array}$ & 19.3 .2006 & NRSC \\
\hline 4 & LANDSAT & MSS & $79 \mathrm{~m}$ & $\begin{array}{l}151 \& \\
042\end{array}$ & $\begin{array}{l}20.11 .197 \\
5\end{array}$ & IIRS \\
\hline 5 & LANDSAT & ETM & $30 \mathrm{~m}$ & $\begin{array}{l}140 \& \\
042\end{array}$ & $\begin{array}{l}28.10 .199 \\
9\end{array}$ & IIRS \\
\hline 6 & LANDSAT & ETM & $30 \mathrm{~m}$ & $\begin{array}{l}141 \& \text { \& } \\
042\end{array}$ & $\begin{array}{l}04.11 .199 \\
9\end{array}$ & IIRS \\
\hline 7 & RADARSAT & $\begin{array}{l}\text { Extende } \\
\mathrm{d} \text { Low } \\
\text { Beam }\end{array}$ & $31 \mathrm{~m}$ & & $\begin{array}{l}13.07 .200 \\
2 \\
08.08 .200 \\
2 \\
09.08 .200 \\
2\end{array}$ & NRSC \\
\hline 8 & $\begin{array}{l}\text { Space Shuttle } \\
\text { Endeavour } \\
\text { (STS 99) }\end{array}$ & $\begin{array}{l}\text { SRTM } \\
\text { (extend } \\
\text { ed } \\
\text { antenna } \\
\text { ) }\end{array}$ & $90 \mathrm{~m}$ & \multicolumn{2}{|c|}{$\begin{array}{l}\text { ffB03_N025E085, } \\
\text { N025E086, } \\
\text { N026E085, } \\
\text { N026E086, } \\
\text { N026E087, } \\
\text { N027E086 }\end{array}$} & $\begin{array}{l}\text { ftp://ftp.g } \\
\text { lcf.umiac } \\
\text { s.umd.ed } \\
\text { u/glcf/SR } \\
\text { TM }\end{array}$ \\
\hline
\end{tabular}

In addition to RS data, hydrographic and hydrological data from Bihar water resources department (WRD) and CWC was also used. The daily Stage data for Dubadhar and Benibad and annual stage and discharge data for Dheng. (Source: HWC, Bihar and CWC, 2006). In this study, 20 field surveyed river cross sections in between Dheng and Benibad are used for HD simulations (Source: FMC, Patna).

The software used in this study are: ERDAS IMAGINE 8.7 for Geometric correction, classification of satellite images \& digitization, ILWIS 3.3 for Hydro processing of DEMs, ARC GIS 9 for DEM visualization, and HEC-RAS \& MIKE-11 to create river database and hydro dynamic modelling. The projection system used in present work is Universal transverse
Mercator (UTM) with WGS 84 datum and spheroid and UTM Zone of 45 North.

\subsection{Methodology}

This work is done in three main parts, as shown in figures 2.1 and 2.2. In the first part of this work, Bagmati River basin delineation, watershed physical characterization in terms of size, shape, slope, stream length, longitudinal slope, stream order etc. was done using SRTM $90 \mathrm{~m}$ DEM (Farr et al. 2007). In the next part, flood inundation was estimated using Radarsat-1 synthetic aperture radar (SAR) data for July-August 2002 flood season.

Next, the flood 1-D HD modelling is done initially, using Hydrologic Engineering Centre - River Analysis System (HECRAS), but due to low slope and flat terrain, HEC-RAS based results were not satisfactory. To overcome limitations of HECRAS, Mike-11 HD model was setup for simulating water level \& flood flow flowchart shown in figure 2.2).

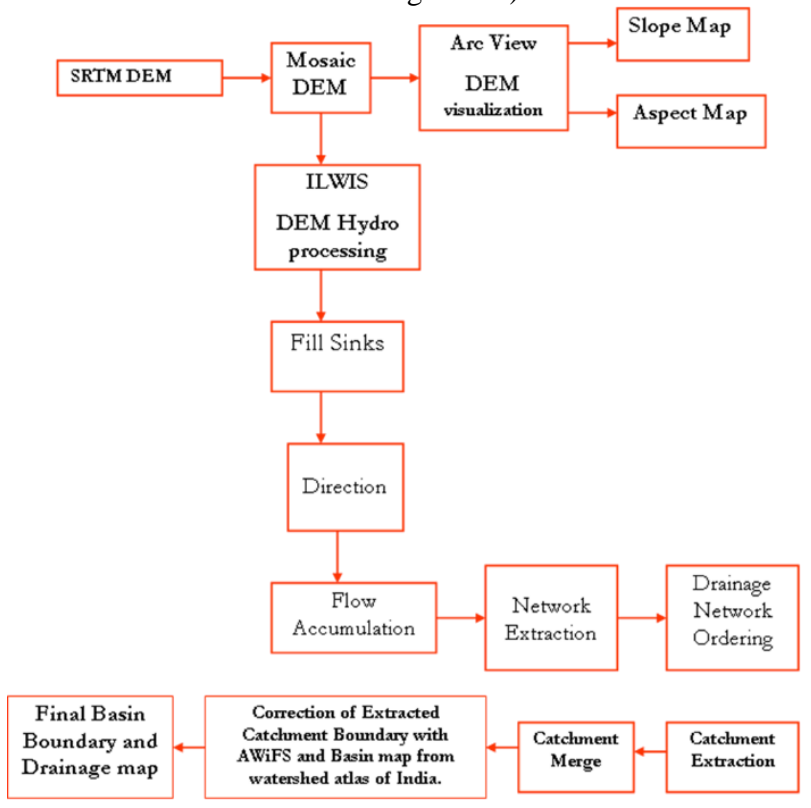

Fig. 2.1. Flowchart for basin hydro-processing

The HD simulation were done from Dheng to Benibad stretch of Bagmati River (shown in 1.2). The input river data for both, HEC-RAS and Mike-11 was created from LISS-III image, flood plain elevation was taken from SRTM DEM and river cross sections were taken from FMC-Patna. 


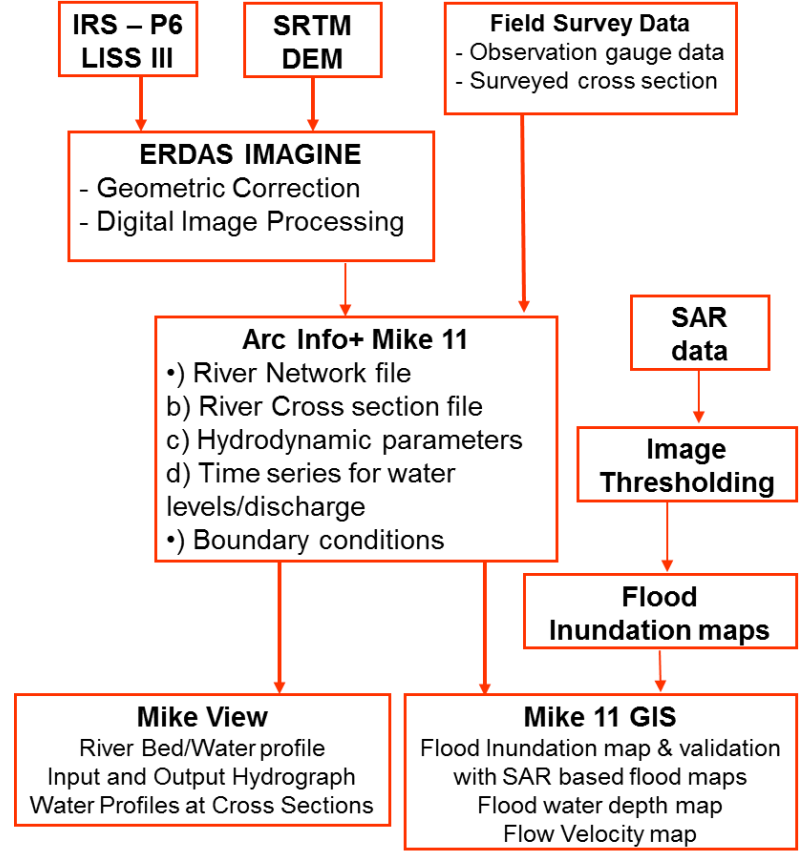

Fig. 2.2. Flowchart for flood inundation mapping and 1-HD modelling and visualization (modified after Thakur \& Sumangla 2006)

The flood inundation map derived from SAR data was also used to validate the flood simulation of HD model.

\section{RESULTS AND DISCUSSIONS}

\subsection{Hydro processing}

The main hydro processing operations to extract drainage network and sub-basin physical parameters for the Bagmati basin are done in ILWIS 3.3 (ITC, 2007). This process is consisting of following major steps, i.e., fill sinks, flow directions, flow accumulations, drainage threshold, sub-basin delineation, DEM re-conditioning if drainage and watershed boundary do not match with ground data, and finally the watershed/river morphometric parameter estimation. The flow chart shown in figure 2.1 gives the sequence of each operations. In the case of Bagmati River basin, the SRTM DEM used for hydro-processing has horizontal and vertical resolution of $90 \mathrm{~m}$ and $16 \mathrm{~m}$ respectively. This caused some error in the flow accumulation map and mixing of extracted drainage map with Kamla-Balan river system (figure 3.1a). Therefore, this data was not used to extract Bagmati basin boundary, instead limited SRTM DEM editing was done by overlaying it on LISS III and AWiFS images.
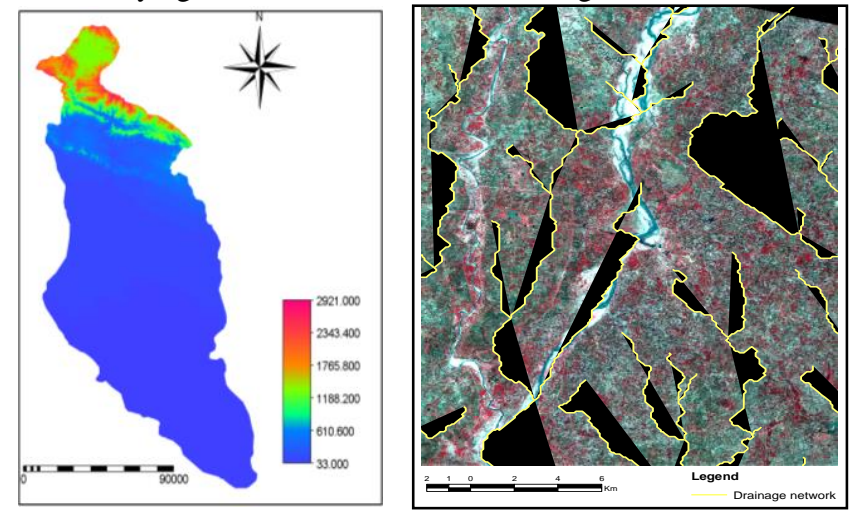

Fig.3.1a: SRTM $90 \mathrm{~m}$ DEM and 3.1b: Image showing derived streams and actual river as seen in LISS-III data.
The mismatch between derived drainage and watershed boundary was corrected by using vector file from watershed atlas of India (1988), updated this vector file with AWIFS/LISS-III image and, applying DEM reconditioning in ILWIS 3.3 DEM-hydro processing tool. The corrected ridge line is shown in figure 3.2, with AWiFs image in the background. This area and drainage basin can further be improved if we use better resolution DEMs.

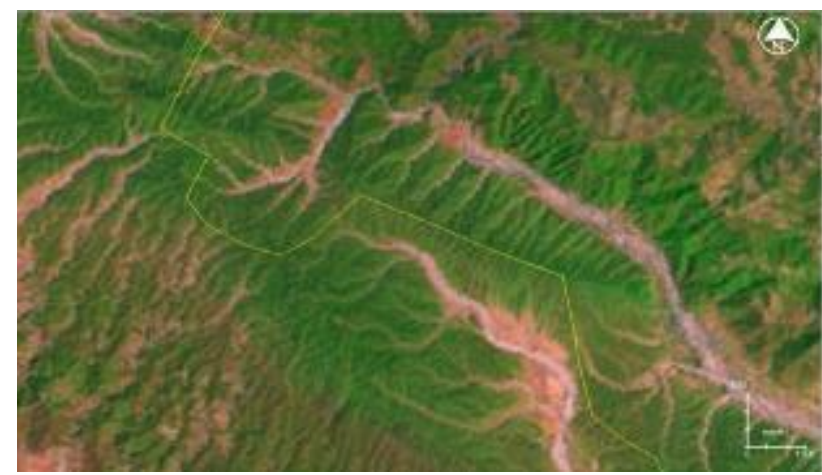

Fig. 3.2. AWiFS image showing ridge line and cliff, correct w.r.t the DEM based basin boundary of Bagmati basin

The final basin boundary and stream network of entire Bagmati basin is shown in figure 3.3. The main Bagmati River and other Adhwara group of Rivers are clearly seen in the figure 3.3.

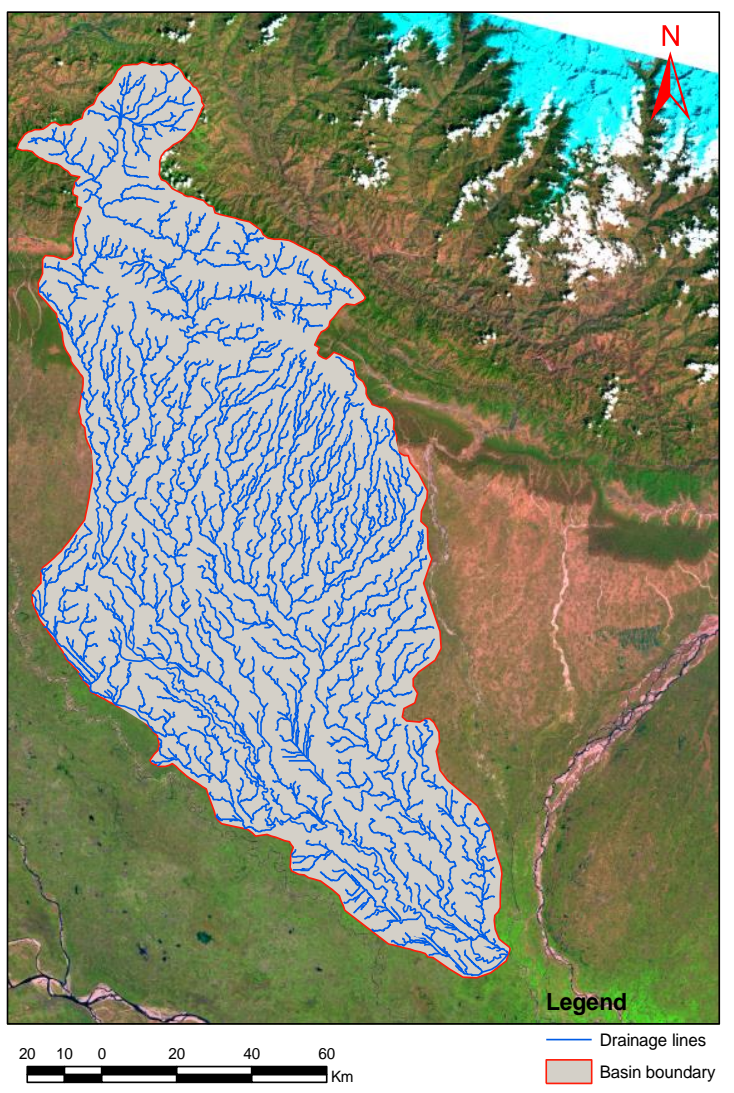

Fig.3.3: AWiFS image with Bagmati basin and drainage network

Total basin area of the Bagmati river system including the Adhwara group of rivers, in Nepal and India both, comes as $15821.91 \mathrm{~km}^{2}$. It is much more than basin area of $14384 \mathrm{~km}^{2}$, mentioned in BSIC, (1994) report and $13,424 \mathrm{~km}^{2}$ as given in India-WRIS. The difference in area can be due to addition of 
Adhwara group of rivers in overall Bagmati basin, and use of DEM updated with latest RS images. Still the area and length of basin need to be validated with more precise DEM of study area and latest high resolution drainage maps based optical or synthetic aperture radar (SAR) images.

\subsection{Flood inundation mapping}

The flood inundation mapping was done using RADARSAT-1 SAR images dated 13 July 2002, 08 August 2002 and 09 August 2002 which were geo referenced using geo referenced LISS III images. These images are smoothened using Lee - Sigma filter for further water pixels extraction using histogram based threshold method. The fig. 3.4 shows example of backscatter image and flood water pixels after a threshold.

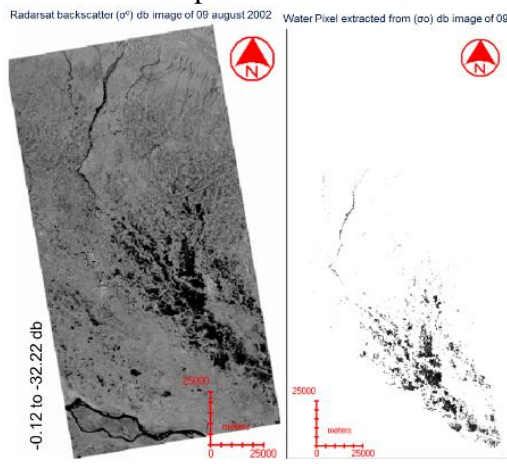

Fig. 3.4: Rdarsat-1 backscatter image with extracted water map.

Total inundation area on 13 July 2002, 08 august 2002 \& 09 August 2002 during flood comes as $114.47 \mathrm{~km}^{2}, 230.42 \mathrm{~km}^{2}$ \& $563.24 \mathrm{~km}^{2}$ respectively. The estimated flooded area (shown in figure 3.5) in based on threshold of digital number (DN) of SAR data, as calibrated Radarsat-1 data was available for 09 Aug. 2002 only. The multiple classes of flooded area is derived using by multiple SAR data threshold, i.e., less than 35 pixel value is taken as water pixels and density slicing is done on this data to various get water depths based water sub-classes, lesser the $\mathrm{DN}$, deeper and calmer is the water body or flood water. The flooded area can further be improved by using calibrated and fully polarimetric SAR data for study area.

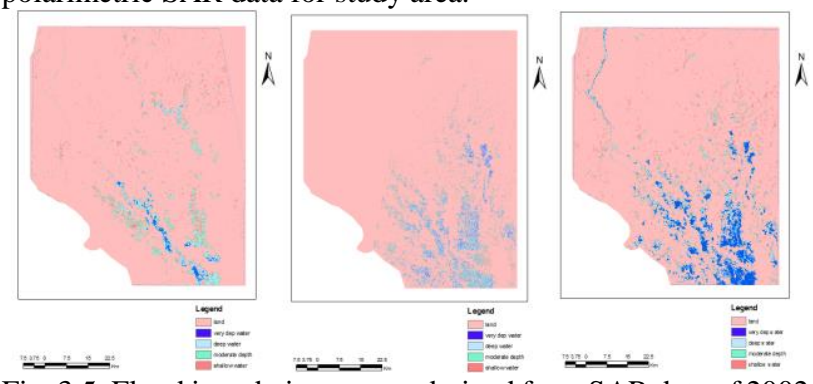

Fig. 3.5: Flood inundation area as derived from SAR data of 2002

\subsection{1-D hydrodynamic flood modelling}

As HEC-RAS HD model could not give satisfactory results this river, the HD modelling was done using Mike-11 HD model. In the mike-11 model, time series data was provided at starting point, i.e., Dheng, river network file, cross section were given in river and cross section editor, and boundary conditions, HD model setting are given in simulation editor. For Dheng, inflow and for Benibad, water level is used as boundary type. The tim period of simulation was taken from $1^{\text {st }}$ August 2002 to 30 September 2002, with 15 minutes time step. Bed resistance is taken as Manning's " $n$ ", with value of 0.05 for river bed and flood plain resistance is kept as 0.20 .

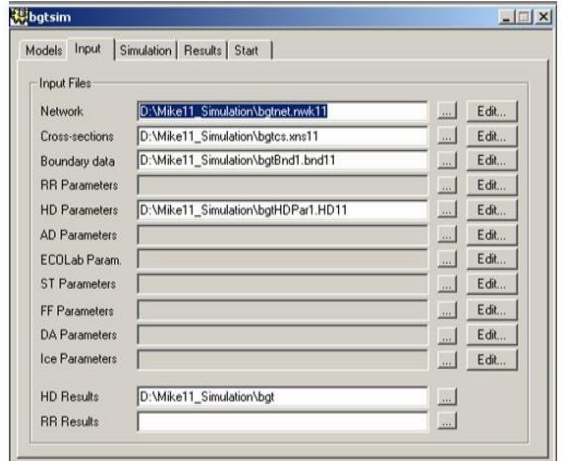

Fig. 3.6: Final simulation editor of mike-11

Once HD simulations are done, the Mike view tool is used to visualize the results for water level and discharge at various cross section of river.

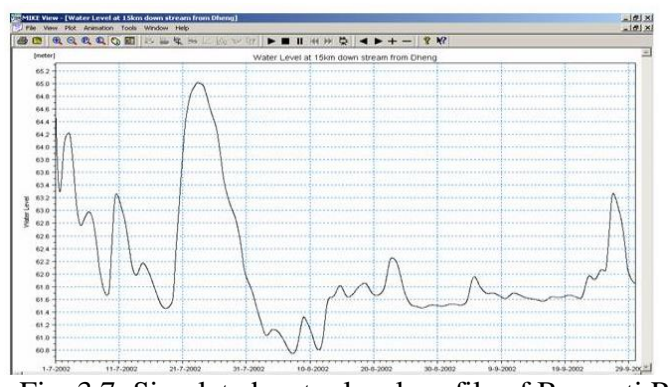

Fig. 3.7: Simulated water level profile of Bagmati River at the cross section, $15 \mathrm{kms} \mathrm{d} / \mathrm{s}$ from Dheng

Table 2: Water levels comparison from current and CWC Hydrodynamic simulation

\begin{tabular}{|c|c|c|}
\hline Distance (m) & $\begin{array}{c}\text { Water Level (m) } \\
\text { ( Simulation 2 } \\
\text { Results) }\end{array}$ & $\begin{array}{c}\text { Water Level } \\
\text { (m) } \\
\text { (CWC Report) }\end{array}$ \\
\hline 0.0 (Dheng) & 70.88 & 74.003 \\
\hline 4890.80 & 70.371 & 69.796 \\
\hline 10146.8 & 69.939 & 69.004 \\
\hline 19536.66 & 67.979 & 67.811 \\
\hline 25025.36 & 65.772 & 65.393 \\
\hline 39456.61 & 61.378 & 62.811 \\
\hline 61411.92 & 61.042 & 59.009 \\
\hline (Runisaidpur) & 61.026 & \\
\hline 66411.87 & 61.023 & - \\
\hline 70236.39 & 60.971 & - \\
\hline 73428.34 & 60.885 & - \\
\hline 78421.44 & 60.043 & - \\
\hline 87120.60 & 56.137 & - \\
\hline 98659.77 & 53.917 & - \\
\hline 103118.70 & 49.755 & - \\
\hline 107223.80 & & - \\
\hline 115188.66 & 70.88 & \\
$($ Benibad) & & \\
\hline & & \\
\hline
\end{tabular}

Table 2 shows the simulated results with actual observed water levels from CWC observations. Comparison was done from Dheng to Runisaidpur stretch of river as observation was available for that part only. The $\mathrm{R}^{2}$ of 0.85 was estimated for this data. It is observed in the study that maximum discharge at Dheng in year 2002, calculated through rating curve is $4319.27 \mathrm{~m}^{3} / \mathrm{s}$ (at Water Level $71.75 \mathrm{~m}$ ), which is more than the 25 year return period flood peak of $3983 \mathrm{~m}^{3} / \mathrm{s}$.

Based on the results of HD simulation, it is observed that we have same results for cross sections between Dheng and Runnisaidpur, 
but slightly different results at Dheng and Runnisaidpur. It can be explained due to extent of reach taken for simulation in two studies. We have started our simulation from Dheng itself, whereas, CWC took Karmaiya in Nepal as its starting point. Variation in cross sections and rating curve (shown in appendix table 3, figure 6) at Dheng may also be the other reason. Longitudinal water profile derived from HD simulations clearly depicts that from Dheng, $22 \mathrm{~km}$ to $39 \mathrm{~km}$ reach is at maximum risk. The embankments between this reach sustain maximum water pressure and are prone to breach (shown in appendix figure 5). After Runnisaidpur, river cross section has very less conveyance area and river flows almost through flood plains.

In year 2002 right embankment of the Bagmati breached at about $31 \mathrm{~km}$. IRS - P6, LISS III image on 24.03 .04 clearly depicts this breach. Texture and colour at that site shows sandy areas at breach locations. Similarly a breach at left afflux bund near Dheng Bridge is also clearly visible in the LISS - III image. This work can further be improved by coupling the mike-11 model with mike-21 model for simulating the flood inundation for this area, provided accurate floodplain DEM and better boundary conditions are available for HD model.

\subsection{Framework for integrated flood modelling and management}

Finally, an integrated framework is proposed for flood modelling and management (figure 3.8) which combines, remote sensing based flood inundation information, various geospatial layers, hydrological and hydrodynamic models, calibration and validation for overall flood management.

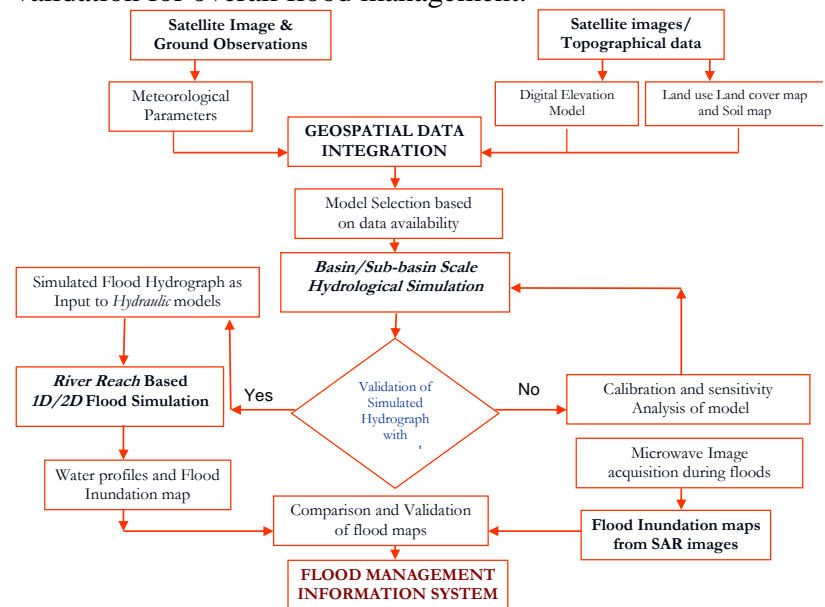

Fig. 3.8. Integrated flood modelling and management information system framework (modified after IIRS-2006).

\section{CONCLUSIONS AND RECOMMENDATIONS}

The delineated basin, extracted drainage network and 1D-HD simulation of the 2002 for Bagmati River using Remote Sensing and GIS have shown the high applicability and usefulness of these tools for river basin flood management. The drainage and basin maps together with DEM of basin can further be used to find the sub-basin area of Bagmati in upstream hilly areas of Nepal and downstream flood plain of India. These georeferenced databases together with rainfall (raingauge/satellite), temperature, other meteorological parameters, basin scale Soil map and landuse - landcover (LULC) map can be used to perform hydrological simulations for complete Bagmati basin. The resultant hydrograph of such hydrological models can be used in near real time as input to hydraulic models at Dheng Bridge. Then this discharge can be routed using combination of
1D/2D hydrodynamic models in GIS environment to see the water levels, discharge and inundated flood areas in the downstream reaches. Thus, a complete flood management information system in near real time can be created based on the current and additional datasets and proper selection of hydrological/hydraulics models for Bagmati basin. The predicted flood inundation area can be verified with the Digital image processing of SAR (RADARSAT, RISAT, ENVISAT and TerraSAR) images during actual flood events.

\section{ACKNOWLEDGEMENTS}

Authors are thankful to Water Resources Department of Bihar, and National Remote Sensing centre, Hyderabad for providing all the required data for completing this work. First author is also thankful for WRD, Bihar for giving him study leave permission to undertake post graduate diploma (PGD) at IIRS Dehradun. Extensive support given by engineers and field staff of WRD, Bihar is also acknowledged.

\section{REFERENCES}

Bakimchandra, O., 2006. Reconstruction of 2003 Daya River Flood,using Multi-resolution and Multi-temporal Satellite Imagery. IIRS-ITC M.Sc. Thesis.

BSIC, Report of the second Bihar State Irrigation Commission, (1994). Flood and Drainage Problem of Bihar and their Remedial Measure. 5(1).

BWRD, 2006. Flood circle, Sitamarhi, Water Resource Department, Patna, Bihar

Chief Engineer office CWC-Patna. (2006). Discharge data of Bagmati, Central Water Commission, Boring road, Patna.

Chandran, V., Ramakrishnan, R.D., Chowdary, V. M., Jeyaram A. and Jha, A. M., 2006. Flood mapping and analysis using airborne synthetic aperture radar: A case study of July 2004 flood in Bagmati river basin, Bihar. Current Science, 90(2), 249-256.

Birkett, C.M., 2000. Synergetic remote sensing of Lake Chad; variability of basin Inundation, Remote Sensing of Environment 72: $218-236$.

Dhar, N. O., Nandagiri Shobha., 1998. Floods in Indian Rivers and their meteorological Aspects, in: Memoir Geological Society of India, Bangalore, pp.1-25.

IIRS, 2007. IIRS lecture notes for post graduate diploma (PGD) course on RS-GIS for natural resources management, water resources division, Indian Institute of Remote Sensing, Dehradun, India.

Frazier. P.S., and Page, K.J., 2000. Water body detection and delineation with Landsat TM data, Photogrammetric Engineering and Remote Sensing, (66): 1461-1467.

FMC, 2006. Flood Control Planning and Monitoring Circle, Water Resource Department, Govt. of Bihar, Patna, Bihar

Kumar, S.S., 2004. Analysis of Uncertainties in Digital Elevation Models in Flood (Hydraulic) Modeling. IIRS-ITC M.Sc. Thesis. 
Farr, T.G., Rosen, P.A., Caro, E., Crippen, R., Duren, R., Hensley, S., Kobrick, M., Paller, M., Rodriguez, E., Roth, L., Seal, D., Shaffer, S., Shimada, J., Umland, J., Werner, M., Oskin, M., Burbank, D., Alsdorf, D., 2007. The Shuttle Radar Topography Mission. Reviews of Geophysics, 45(2): RG2004.

Townsend, P.A., and Walsh, J. S., 1998. Modeling floodplain inundation using an integrated GIS with radar and optical remote sensing. Geomorphology, (21): 295-312

Smith, L.C., 1997. Satellite remote sensing of River inundation area, Stage, and Discharge: A Review. Hydrological Processes, 11: $1427-1439$

Toyra, J. and W.Martz, L., 2001. Multi-sensor Hydrological Assessment of a Freshwater Wetland. Remote sensing of Environment, (75): 162-173.

Tholey, N., Clandillion, S. and Fraipont, P.D., 1997. The contribution of Space borne SAR and Optical data in monitoring Flood events: Examples in northern and southern France. Hydrological Processes, (11): 1409-1413.

Subramanya, K., 2008. Engineering Hydrology, Tata Mc GrawHill Publishing Company Limited, New Delhi.

Thakur P.K., and Accarapol, S., 2006. Flood inundation mapping and 1-D hydrodynamic modeling using remote sensing and GIS techniques. ISPRS Orange Book Publication, of ISPRS/ISRS commission IV symposium on "Geospatial Database for Sustainable Development" at GOA, India, 27-30, 2006, pp-1-6, http://www.isprs.org/proceedings/XXXVI/part4/WG-VIII-2-9.pdf.

United Nations, U.N., 2002. Guidelines for Reducing Flood Losses, Editor, Paul J. Pilon, A joint publication of UN, A contribution to the International Strategy for Disaster Reduction. Department of Economic and Social Affairs (DESA), Division for Sustainable Development, UN Inter-Agency Secretariat of the International Strategy for Disaster Reduction (UN/ISDR), National Oceanic and Atmosphere Administration (USA NOAA), and the Swiss Agency for Development and Cooperation (SDC). Pp-1-79.

www.fmiscwrdbihar.gov.in

https://www.itc.nl/ilwis/download/ilwis33/

http://www2.jpl.nasa.gov/srtm

https://india-wris.nrsc.gov.in

\section{APPENDIX}

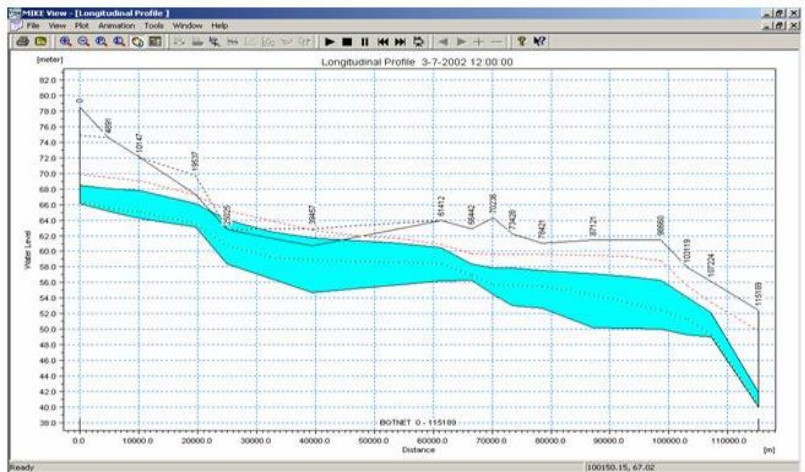

Fig. 4.0. Longitudinal Water profile with maximum water level at Runnisaidpur on 03.7 .02 at 12.00

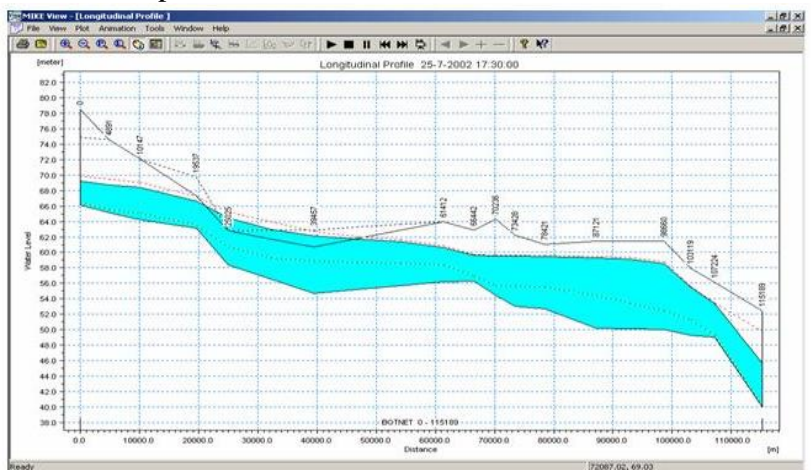

Fig. 4.1. Longitudinal Water profile with maximum level at Runnisaidpur and Mathrapur Joki on 25.7.02 at 12.00

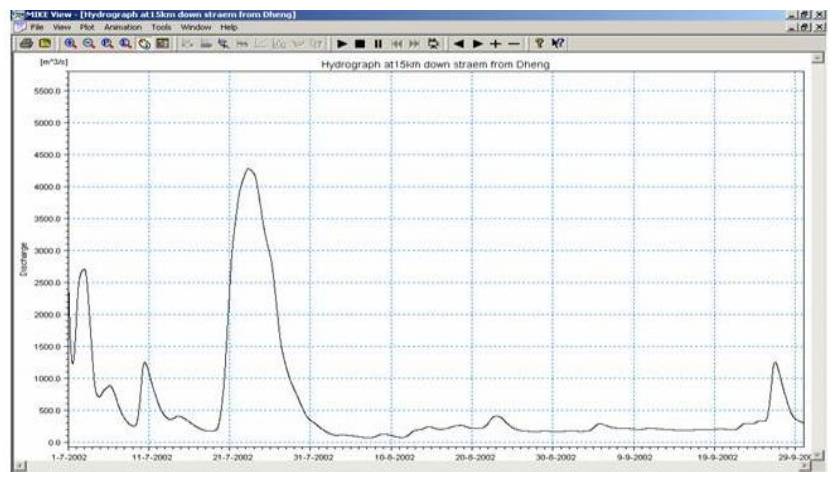

Fig. 4.2: Hydrograph at the cross section, $15 \mathrm{~km} . \mathrm{d} / \mathrm{s}$ from Dheng

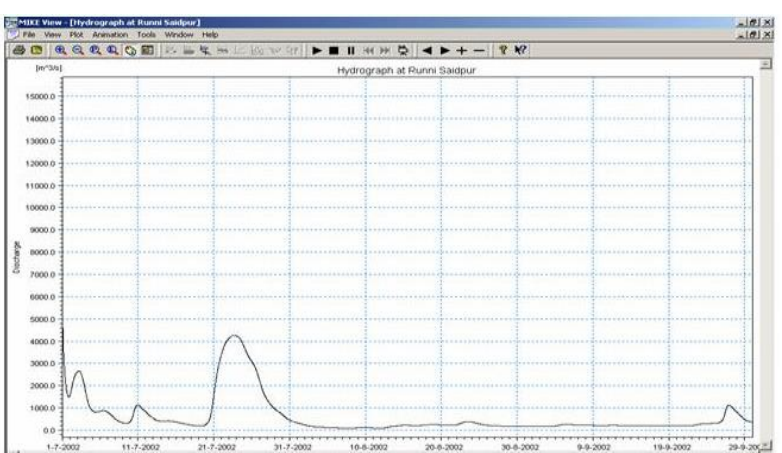

Fig. 4.3: Simulated Hydrograph at Runni Saidpur, $61.41 \mathrm{~km}$ from Dheng

Field photographs collected during field survey of October 2006. 


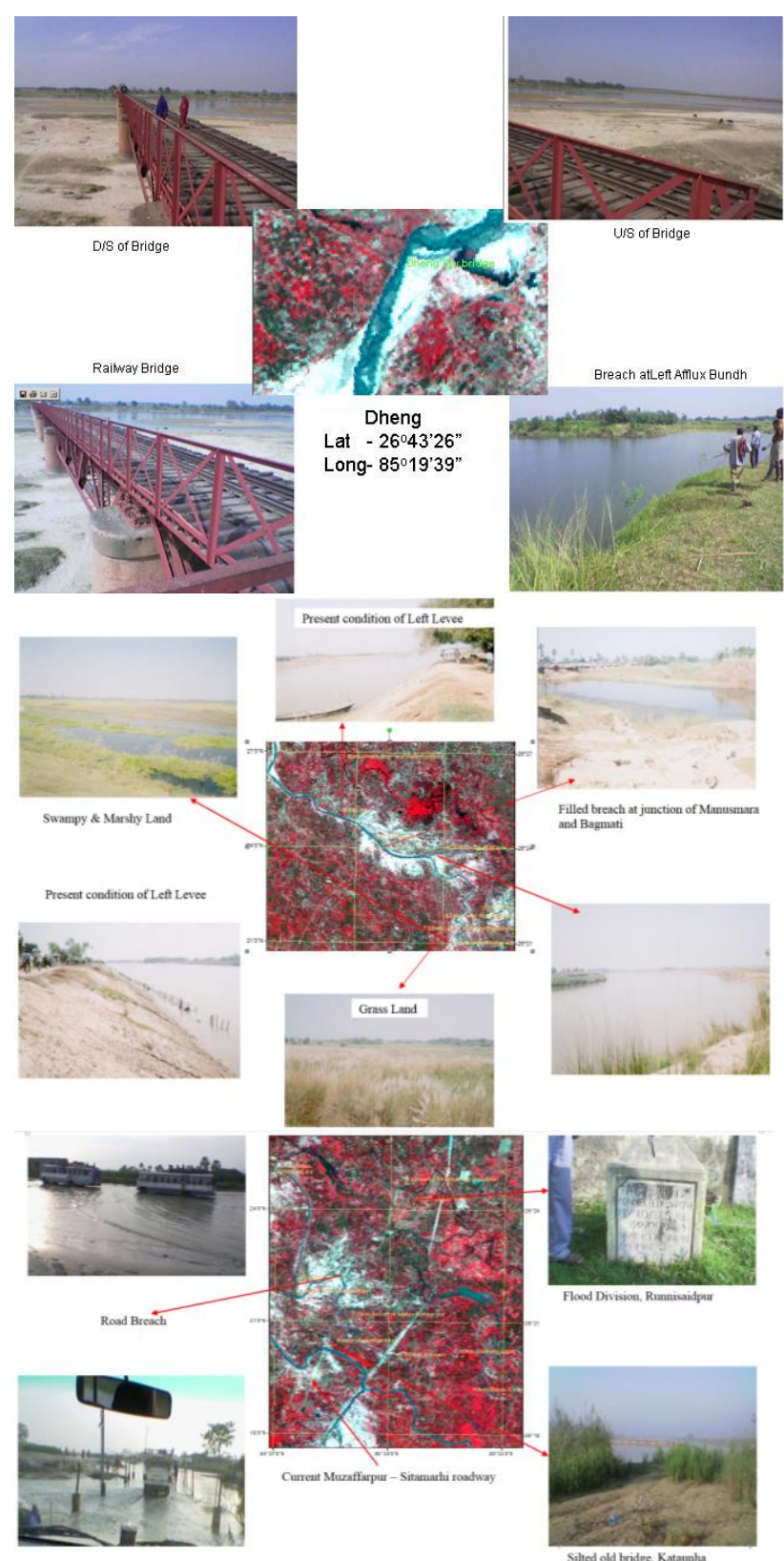

Fig. 5: Field pictures of study area, showing inflow point Dheng, breach points and one of the cross sections at Runni Saidpur (Source: Rastogi and Thakur, field survey 2006).

\section{Rating curve at Dheng}

Exponential equation is used to draw rating curve between measured sate and discharge data.

Table 3: Peak water level and flow at Dheng site

\begin{tabular}{|c|c|c|c|}
\hline S.No. & Year & $\begin{array}{c}\text { Max } \\
\text { m. } \\
\text { Observed } \\
\text { Gauge( } \mathbf{m} \text { ) }\end{array}$ & $\begin{array}{c}\text { Max } \\
\text { Discharge } \\
\text { Discher } \\
\text { corresponding to } \\
\text { max }^{\mathbf{m}} \text {.observed } \\
\text { gauge( cumecs })\end{array}$ \\
\hline 1 & 1970 & 71.5 & 3287 \\
\hline 2 & 1971 & 71.33 & 2459 \\
\hline 3 & 1972 & 71.35 & 2510 \\
\hline 4 & 1973 & 70.97 & 1423 \\
\hline 5 & 1974 & 71.08 & 1684 \\
\hline 6 & 1975 & 72 & 5165 \\
\hline
\end{tabular}

\begin{tabular}{|c|c|c|c|}
\hline 7 & 1976 & 70.4 & 1014 \\
\hline 8 & 1977 & 70.65 & 1158 \\
\hline 9 & 1978 & 71.68 & 3762 \\
\hline 10 & 1979 & 71.25 & 2118 \\
\hline 11 & 1980 & 70.38 & 956 \\
\hline 12 & 1981 & 71.08 & 1684 \\
\hline 13 & 1982 & 71.02 & 1518 \\
\hline 14 & 1983 & 70.89 & 1357 \\
\hline 15 & 1984 & 71.8 & 4264 \\
\hline 16 & 1985 & 71.8 & 4264 \\
\hline 17 & 1986 & 71.05 & 1600 \\
\hline 18 & 1987 & 71.04 & 3600 \\
\hline 19 & 1988 & 70.88 & 1348 \\
\hline 0 & 1989 & 70.75 & 1238 \\
\hline
\end{tabular}

(Source: BSIC-1994)

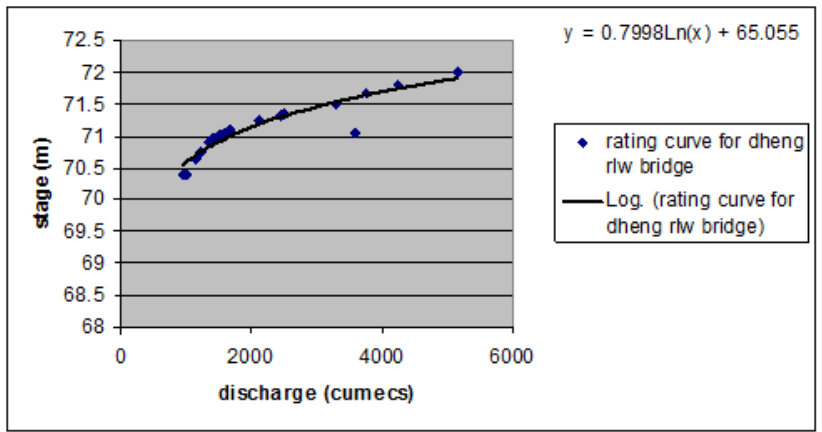

Fig. 6 Rating curve at Dheng 